\title{
Age of high-grade gneisses south of Grand Lake, Newfoundland
}

\author{
K.L. Currie, O. van Breemen, P.A. Hunt and J.T. van Berkel* \\ Geological Survey of Canada, 601 Booth Street, Ottawa, Ontario K1A OE8, Canada
}

Date Received April 29, 1991

Date Accepted October 21, 1991

\begin{abstract}
Crystalline rocks of the Steel Mountain Subzone of the Humber Zone in southwest Newfoundland give an age for granulite-grade metamorphism of $1498+9 /-8 \mathrm{Ma}$, similar to ages from the Long Range inlier and northwestern Cape Breton Island. Peralkaline leucogranite was emplaced at $608 \pm 4 \mathrm{Ma}$. The emplacement of anorthosite-gabbro complexes and amphibolite-grade metamorphism took place between these dates. The southern part of the Dunnage Zone (Central Gneiss Subzone), in contact with the Steel Mountain Subzone at the Long Range Fault, lacks Precambrian crystalline rocks, but was intruded by charnockitic plutons and metamorphosed to granulite facies at 460 $\pm 10 \mathrm{Ma}$. This subzone was exhumed before $435 \mathrm{Ma}$. In the Meelpaeg Subzone of the Gander Zone, which is in contact with the Central Gneiss Subzone along the Victoria River Fault, the oldest intrusive component of a granoblastic migmatitic gneiss was emplaced at $418 \pm 4 \mathrm{Ma}$.

These data demonstrate that both the Long Range and Victoria River faults form major tectonic boundaries. Subzones appear to have been thrust westward in Silurian or later time.
\end{abstract}

Les roches cristallines de la sous-zone du mont Steel, dans la zone de Humber du sud-ouest de Terre-Neuve, ont donné des âges de 1498+9/-8 Ma pour le métamorphisme de haut grade, similaires à ceux de la boutonnière de Long Range et du nord de l'Ile-du-Cap-Breton. Un leucogranite peralcalin s'est mis en place à $608 \pm 4$ Ma. L'intrusion des complexes à anorthosite-gabbro et le métamorphisme au faciès amphibolite se sont produits entre ces deux évènements. La partie sud de la zone de Dunnage (sous-zone de gneiss centrale), en contact avec la sous-zone du mont Steel à la faille de Long Range, ne contient pas de roches cristallines précambriennes mais a été recoupée par des plutons charnockitiques et a été métamorphisée au faciès granulite à $460 \pm 10 \mathrm{Ma}$. Cette sous-zone a été exhumée avant $435 \mathrm{Ma}$. Dans la sous-zone Mulpaeg de la zone de Gander, qui est mise en contact avec la sous-zone de gneiss centrale par la faille de la rivière Victoria, la phase intrusive la plus ancienne d'un gneiss migmatitique et granoblastique s'est mise en place à $418 \pm 4 \mathrm{Ma}$.

Ces données démontrent que les failles de Long Range et de la rivière Victoria sont des frontières tectoniques majeures. Les sous-zones semblent avoir subi un chevauchement vers l'ouest au plus tard au Silurien.

[Traduit par le journal]

\section{INTRODUCTION}

Central and western Newfoundland exhibit the products of subduction of oceanic plate and eventual continent-continent collision (Bird and Dewey, 1971), but timing of subduction and the location of the suture zone(s) between colliding continental blocks remain uncertain. Zonal hypotheses (for example, Williams, 1979; Williams et al., 1988) assume that vestiges of the pre-collision(s) geometry of the orogen persist, although distorted and transported, in the form of subzones or chains of terranes longitudinally spread along the orogen (Fig. 1) and separated from one another by major faults. According to these hypotheses, the Humber Zone represents the North American plate with relicts of deformed and transported shelf and rise prism. The Dunnage Zone consists of relicts of ocean floor and superincumbent volcanic and sedimentary rocks, whereas the Gander Zone comprises a continental rise prism of uncertain source, possibly derived from the Avalon Zone which in Newfoundland consists of late Precambrian and younger supracrustal rocks. The Dunnage Zone is now thought to be entirely allochthonous (Currie $e t$ al., 1979; Colman-Sadd and Swinden, 1984; Kean et al., 1986; Marillier et al., 1988) and hence does not necessarily give any information on the tectonic history of underlying subzones.

South of Grand Lake, rocks typical of the Dunnage Zone are absent (Fig. 2) and deeper seated subzones or zones appear to be in contact (van Berkel and Currie, 1988). Geochronology of the southeastern part of this region has been investigated by Dunning et al. (1988), but geochronological information on the northwestern part is sparse. In particular, the character and extent of Precambrian basement remain uncertain. We here present results of a search for basement in a recently mapped region south of Grand Lake.

*Present address: Department of Earth Sciences, Free University, P.O. Box 7161, 1007 MC Amsterdam, The Netherlands

Geological Survey of Canada Contribution No. 57365 


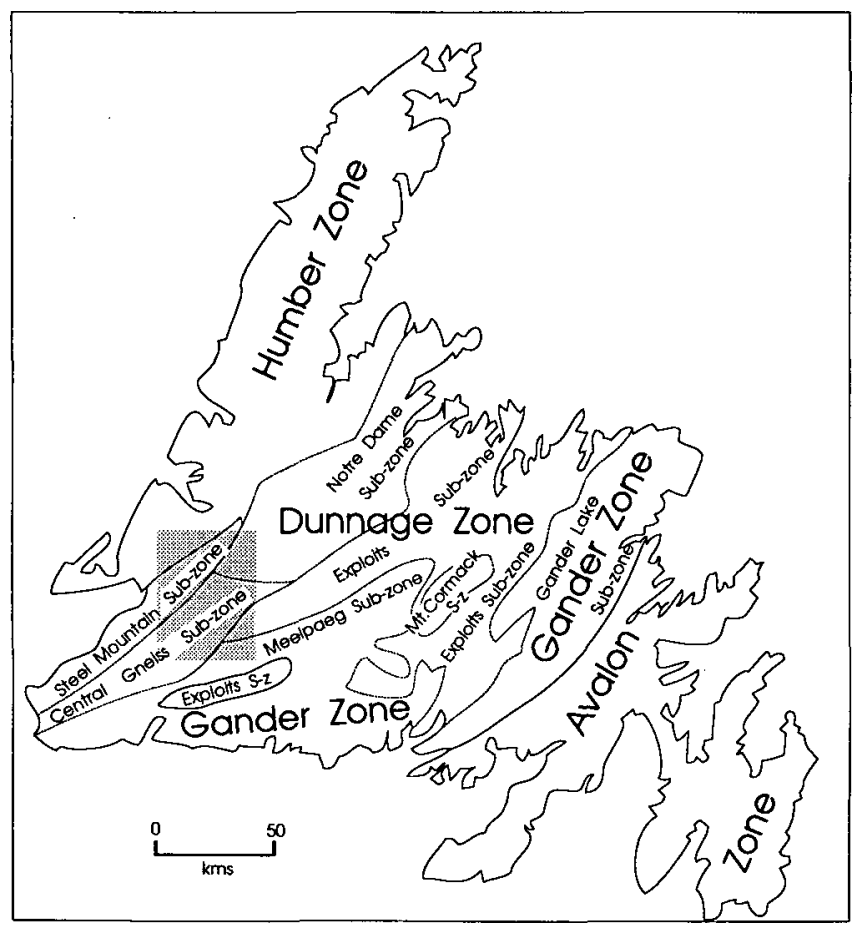

Fig. 1. Tectonostratigraphic zones of Newfoundland [modified after Williams et al. (1988)]. Zone boundaries shown by heavy broken lines, subzone boundaries by light broken lines. The Mt. Cormacks Subzone belongs to the Gander Zone. The location of Figure 2 is shown by the shaded box.

\section{Regional Geology}

The region south and southeast of Grand Lake (Fig. 2) falls into subzones bounded by major faults. West of the Grand Lake Fault, Cambro-Ordovician sedimentary rocks represent the ancient passive margin shelf of North America (Humber Zone of Williams, 1979) imbricated westward in Arenig to Llandeilo time (Williams and Stevens, 1974). Williams and Cawood (1986) noted that deformation and metamorphism increase toward the Grand Lake Fault, a vertically dipping zone 150 to $500 \mathrm{~m}$ in width in which a complex early ductile history has been almost totally obliterated by late brittle deformation (Currie, 1987). Between the Grand Lake and Long Range faults, crystalline rocks of the Steel Mountain Subzone appear in a sequence of westerly transported thrust slices. The oldest recognizable unit comprises felsic to intermediate two-pyroxene granulite-facies gneisses of the Disappointment Hill complex (Currie, 1987) variously retrogressed and reworked on ductile shear zones. The Steel Mountain complex, a massif of anorthositic to gabbroic rocks more than $50 \mathrm{~km}$ in length, cuts and includes granulite-facies gneisses of the Disappointment Hill complex. A gabbroic margin of the Steel Mountain complex exhibits strong gneissic foliation and becomes amphibolitic near the Long Range Fault. Gneisses younger than the Steel Mountain complex contain minor quartzite and crystalline limestone horizons in a granitic and amphibolitic matrix. This gneissic sequence is in turn unconformably overlain by

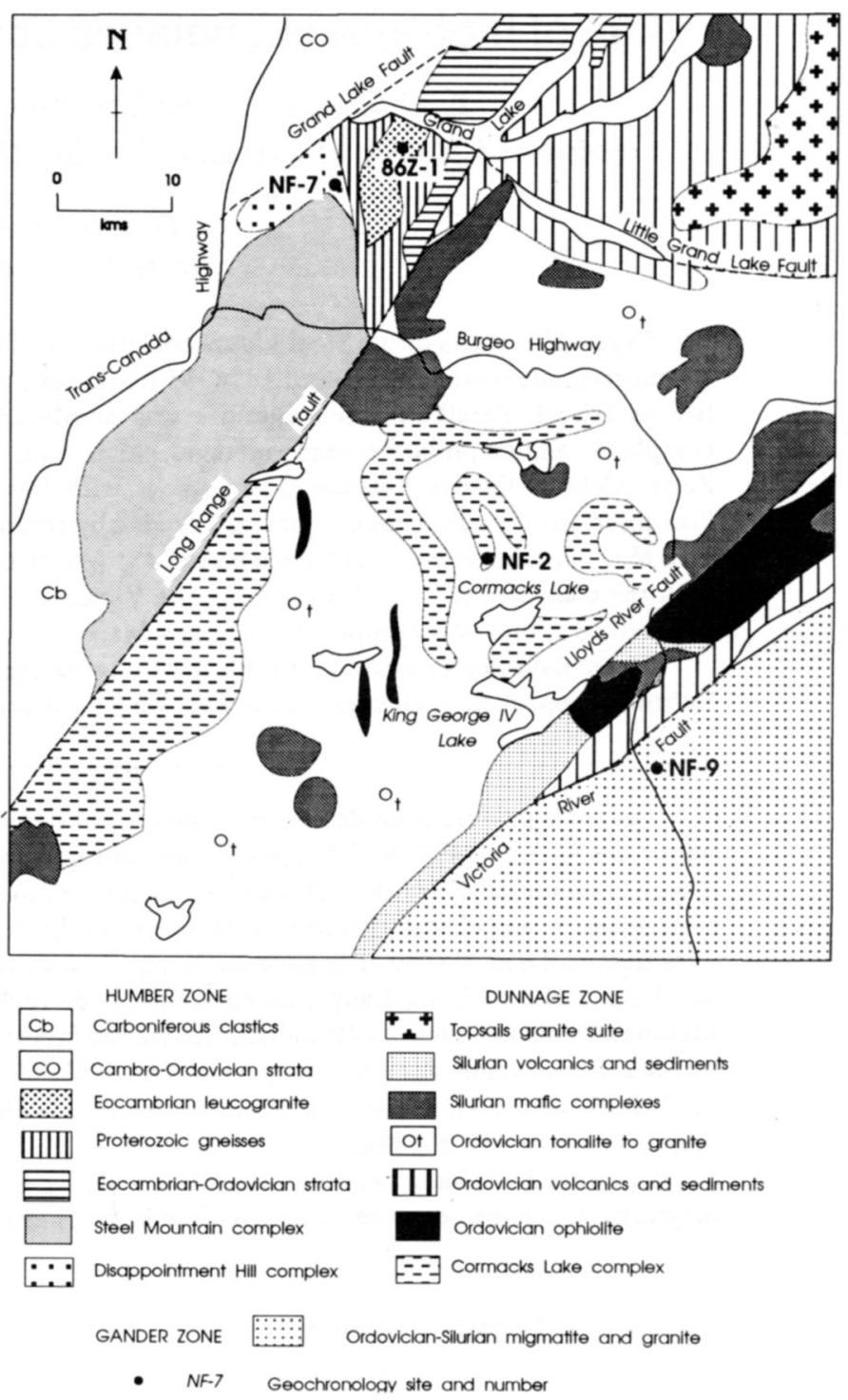

Fig. 2. Geological sketch of southwestern Newfoundland (geology after van Berkel and Currie, 1988) showing location of zircon samples in Table 1.

a sequence of staurolite-kyanite grade metasedimentary schists of the Late Precambrian-Early Paleozoic Fleur de Lys Supergroup (Knapp et al., 1979; Hibbard, 1983; Currie, 1987). Leucocratic alkaline to peralkaline granites intruded the metasedimentary rocks. All units of the Steel Mountain Subzone have been affected by late penetrative deformation associated with low-angle north-northwest-directed thrusting associated with a low-grade overprint in the gneisses (Currie, 1987).

No correlatives of the Steel Mountain Subzone have been positively identified east of the Long Range Fault in the Central Gneiss Subzone. The Central Gneiss Subzone comprises highly metamorphosed supracrustal rocks (Cormacks Lake complex) invaded by voluminous, generally foliated tonalitic to granitic plutons of Ordovician $(\sim 460 \mathrm{Ma})$ age (Stevens et al., 1982; Dunning et al., 1988) and cut posttectonically by mafic plutons of Silurian age (431 Ma, Dunning 
et al., 1988). Felsic and mafic gneisses of the Cormacks Lake complex preserve small areas of granulite-facies metamorphism and larger areas of retrograded gneisses (Herd and Dunning, 1979). Metasedimentary rocks just east of the Long Range Fault have recrystallised to coarse $(>2 \mathrm{~mm})$ granoblastic fabrics difficult to distinguish from granitoid plutons (van Berkel and Currie, 1988) and may also have reached granulite facies. The Central Gneiss Subzone contains thin $(<500 \mathrm{~m})$ strips of ophiolite bounded by high strain zones (Fox and van Berkel, 1988), as well as larger sheets of ophiolite (Brown, 1977) intruded by the tonalite-granite complex (Dunning and Chorlton, 1985). All rocks exhibit a late, greenschist or lower grade metamorphic overprint.

To the north, the Central Gneiss Subzone contacts the Notre Dame Subzone of the Dunnage Zone (Williams et al., 1988) along the Little Grand Lake Fault (Fig. 2, van Berkel and Currie, 1988). The Notre Dame Subzone exhibits lowgrade mafic and felsic volcanics of lower to mid-Ordovician age and locally ophiolitic affinities (Glover and Buchans Groups, Nowlan and Thurlow, 1987), unfoliated mid-Ordovician tonalitic to granitic plutons ( $460 \mathrm{Ma}$, Whalen et al., 1987), and a highly distinctive suite of Silurian A-type granites (Whalen et al., 1987; Whalen and Currie, 1990). To the east, the Lloyds River Fault truncates the Central Gneiss Subzone against the Exploits Subzone of the Dunnage Zone (Fig. 2, Williams et al., 1988), which consists of the lower Ordovician Annieopsquotch ophiolite complex, mid-Ordovician Victoria Lake Group of mafic to felsic volcanic rocks, and outliers of Silurian redbeds and rhyolitic volcanic rocks (Dunning, 1987). South of Annieopsquotch complex the Victoria River Fault juxtaposes the Central Gneiss Subzone against the Meelpaeg Subzone of the Gander Zone which consists of psammitic sedimentary rocks which were deformed, migmatised and intruded by S-type granites in Silurian time (Williams et al., 1988; Dunning et al., 1988).

\section{Sample Selection and Description}

\section{Steel Mountain Subzone}

Previous compilations have generally suggested that rocks of the Steel Mountain Subzone are of Precambrian age (Williams, 1978; Knapp et al., 1979), but relative ages of the units were poorly known [compare the relative age of the Hare Hill granite in Knapp et al. (1979) and Currie (1987)], and some evidence suggested that the Steel Mountain massif could be of Paleozoic age (Riley, 1962; Leech et al., 1963; Murthy and Rao, 1976). No comparisons between this subzone and nearby Precambrian crystalline terranes such as the Indian Head complex (Heyl and Ronan, 1954; Lowdon et al., 1963), the northern Long Range (Baadsgaard et al., in press) or northern Cape Breton Island (Barr et al., 1987) could be attempted because of lack of chronological data.

We have attempted to determine the age of the oldest plutons in the Steel Mountain Subzone and the age of the youngest granitoid rocks in this region (Hare Hill granite). To attack these problems we selected samples from the Disap- pointment Hill complex and the Hare Hill granite. Locations are given in Figure 2 and petrographic descriptions follow.

The Disappointment Hill complex comprises felsic to mafic or intermediate two-pyroxene granulite-facies gneisses layered on a meter scale. The dated sample, from a leucocratic band some $50 \mathrm{~m}$ wide, has a homogeneous, weakly foliated granoblastic texture, and consists of mosaic quartz, fine string mesoperthite $\left(\mathrm{An}_{25}\right)$, augite, hypersthene, and minor biotite and garnet. There is no evidence of retrogression in the sample, although other specimens exhibit development of amphibole haloes on pyroxene, coarse patch perthite, and gradation to foliated porphyroblastic hornblendebiotite granite along high strain zones. The granulite-facies gneisses are cut by dykes of salmon pink to pale orange aplite or pegmatite related to the nearby Hare Hill granite.

The sample of Hare Hill granite was collected from an outcrop tens of meters across near a survey marker at the summit of the hill. The rock is massive, homogeneous coarsegrained leucogranite varying from pink to pale red in colour, and consists largely of subhedral string perthite grains, many showing relict Carlsbad twins, with interstitial quartz and minor acmitic pyroxene and relics of arfvedsonite replaced by riebeckite. Quartz and feldspar have been locally recrystallised along cracks or at the margins of grains ("mortar texture").

\section{Central Gneiss Subzone}

There is no consensus about the age of the oldest rocks in the Central Gneiss Subzone. Herd and Dunning (1979) assigned a Precambrian age to granulite-grade metamorphism of the Cormacks Lake complex. van Berkel and Currie (1988) argued that units could be correlated across the Long Range Fault and that much of the protolith could be Precambrian, although strongly reworked during the Paleozoic. Dunning and Chorlton (1985) suggested that the oldest rocks were lower Ordovician ophiolites.

Dunning (1987) demonstrated that the pervasive tonalite to granite suite is of mid-Ordovician age ( $456 \mathrm{Ma}$ ), but the age of the granulite-facies metamorphism could be older. To investigate this question, we collected fresh, homogeneous, leucocratic charnockite from the Cormacks Lake complex (Herd and Dunning, 1979). This specimen consists mainly of subhedral large grains of string perthite, extensively recrystallised around their margin, with local conversion to microcline. Mafic minerals consist of augite, hypersthene, and hornblende developed at the expense of hypersthene. This rock forms a pluton with a granulite-facies mineral assemblage within a generally amphibolite-grade complex containing local quartzite and gedrite-cordierite enclaves.

\section{Meelpaeg Subzone}

Precambrian rocks have been found in the Meelpaeg Subzone on the south coast of Newfoundland (Dunning et al., 1988), but their extent remains uncertain. Complex migmatites south of Peter Strides Pond consist of granoblastic 
mesocratic biotite gneiss with small potash feldspar porphyroblasts, and numerous nebulous foliated granitoid lenticles, cross-cut by massive coarse leucogranite sills and dykes. The grade of metamorphism resembles that in the Central Gneiss Subzone (van Berkel, 1987). We have sampled the older foliated rocks in a quarry just off the Burgeo highway near Peter Strides Pond. We interpret this material to represent the oldest metamorphic event in this part of the Meelpaeg Subzone, which here affected high-grade psammitic sedimentary rocks.

\section{Geochronology - Analytical Results}

The locations of samples from which zircons were separated are plotted in Figure 2, and zircons are described in Appendix 1. General techniques of zircon concentration, preparation, chemical dissolution and isotopic analysis have been described by Parrish et al. (1987). All zircon fractions were strongly abraded before analysis (Krogh, 1982). The two sigma uncertainties in the isotopic ratios are $0.5 \%$ for ${ }^{206} \mathrm{~Pb} /{ }^{238} \mathrm{U}$ and ${ }^{207} \mathrm{~Pb} /{ }^{235} \mathrm{U}$ and $0.1 \%$ for ${ }^{207} \mathrm{~Pb} /{ }^{206} \mathrm{~Pb}$. Results are presented in Table 1 and displayed in concordia plots in Figures 4 to 6.

\section{Disappointment Hill complex}

The dated sample, a felsic granulite-facies gneiss collected from the northeast side of Disappointment Hill, is considered to represent a pluton metamorphosed with the intermediate to mafic gneisses of the complex. Data points corresponding to five zircon fractions are linearly aligned with the highest point corresponding to the coarsest abraded fraction (Fig. 3). This pattern would be consistent with older cores to the zircons, but no cores are evident on either etched or unetched grain mounts. A regression line to the data points according to the procedures of York (1969) yields upper and lower intercept ages of $1498+9 /-8 \mathrm{Ma}$ and $840 \pm 25 \mathrm{Ma}$ with a mean square of weighted deviates (MSWD) of 8.6. The latter value indicates a significant component of scatter beyond analytical uncertainty. This scatter could be due to recent lead loss, but such an effect may not be very great because the $U$ concentrations are low and because there is no

Table 1. U-Pb zircon analytical data.

\begin{tabular}{ccccccccccc}
\hline $\begin{array}{c}\text { Fraction } \\
\text { size }\end{array}$ & $\mathrm{Wt}$ & $\mathrm{U}$ & $\mathrm{Pb}$ & ${ }^{206} \mathrm{~Pb}$ & $\mathrm{~Pb}_{\mathrm{c}}$ & ${ }^{208} \mathrm{~Pb}$ & ${ }^{206} \mathrm{~Pb}$ & ${ }^{207} \mathrm{~Pb}$ & $\mathrm{R}$ & $\begin{array}{c}207 \mathrm{~Pb} \\
206 \mathrm{~Pb}\end{array}$ \\
\hline
\end{tabular}

1. Disappointment Hill complex (NF-7)

\begin{tabular}{|c|c|c|c|c|c|c|c|c|c|c|c|}
\hline$a_{1}+74 \mathrm{~N} 1$ & 0.021 & 117 & 30 & 1193 & 31 & 10.4 & $0.24258 \pm .09$ & $3.0484 \pm .12$ & 0.87 & $0.09114 \pm .06$ & $1449.5 \pm 2.4$ \\
\hline b, $+74 \mathrm{~N} 1$ & 0.076 & 167 & 42 & 10348 & 18 & 9.6 & $0.24260 \pm .08$ & $3.0507 \pm .10$ & 0.95 & $0.09120 \pm .03$ & $1450.8 \pm 1.1$ \\
\hline c, $-74 \mathrm{~N} 1$ & 0.342 & 215 & 46 & 46841 & 20 & 7.5 & $0.21095 \pm .09$ & $2.5078 \pm .10$ & 0.96 & $0.08622 \pm .03$ & $1343.1 \pm 1$ \\
\hline d, $+62 \mathrm{M} 1$ & 0.324 & 179 & 39 & 44328 & 17 & 8.5 & $0.21423 \pm .09$ & $2.5690 \pm .10$ & 0.96 & $0.08697 \pm .03$ & 1359.9 \\
\hline e, $-62 \mathrm{M} 1$ & 0.160 & 141 & 34 & 13261 & 24 & 9.5 & $0.23427 \pm .08$ & $2.9041 \pm .10$ & 0.96 & $0.08991 \pm .03$ & 1423.6 \\
\hline
\end{tabular}

2. Hare Hill granite (86-Z-1)

\begin{tabular}{|c|c|c|c|c|c|c|c|c|c|c|c|}
\hline $\mathrm{a},+149$ NO & 0.172 & 290 & 29 & 1286 & 243 & 10.2 & $0.09798 \pm .10$ & $0.8124 \pm .13$ & 0.87 & $0.06013 \pm .07$ & $608.4 \pm 2.9$ \\
\hline b, +105 N0 & 0.213 & 266 & 26 & 1547 & 232 & 10.0 & $0.09768 \pm .10$ & $0.8095 \pm .13$ & 0.85 & $0.06010 \pm .07$ & $607.3 \pm 3.0$ \\
\hline c. $+105 \mathrm{NO}$ & 0.173 & 358 & 36 & 3134 & 122 & 11.3 & $0.09792 \pm .10$ & $0.8118 \pm .12$ & 0.91 & $0.06012 \pm .05$ & $8.0 \pm 2.2$ \\
\hline $\mathrm{d},+105 \mathrm{M} 0$ & 0.146 & 278 & 27 & 1208 & 206 & 10.0 & $0.09633 \pm .11$ & $0.7947 \pm .14$ & 0.85 & $33 \pm .07$ & \pm 3.2 \\
\hline e, -105 M0 & 0.127 & 264 & 26 & 1039 & 201 & 10.2 & $4 \pm .10$ & $0.8054 \pm .14$ & 0.85 & $0.06001 \pm .08$ & 3.3 \\
\hline f, -105 NO & 0.015 & 350 & 35 & 2966 & 11 & 10.2 & $0.09840 \pm .09$ & $0.8156 \pm .10$ & 0.93 & $5011 \pm .04$ & 1.7 \\
\hline g, -105 NO & 0.004 & 323 & 32 & 519 & 14 & 10.5 & $0.09835 \pm .14$ & $0.8124 \pm .19$ & 0.80 & $0.05991 \pm .11$ & $600.2 \pm 5.0$ \\
\hline
\end{tabular}

3. Cormacks Lake complex (NF-2)

$\begin{array}{llllrll}\text { a, +149 } & 0.109 & 766 & 58 & 16860 & 23 & 12.8 \\ \text { b, +105 NM1 } & 0.072 & 354 & 27 & 6443 & 18 & 13.2 \\ \text { c, +100 M1 } & 0.041 & 462 & 32 & 1635 & 50 & 11.8 \\ \text { d, -105 M1 } & 0.003 & 256 & 19 & 341 & 13 & 12.1 \\ \text { e, -105 NM1 } & 0.079 & 413 & 31 & 8806 & 17 & 11.8\end{array}$

$0.07245 \pm .10$ $0.07236 \pm .10$ $0.06729 \pm .09$ $0.07348 \pm .29$ $0.07339 \pm .09$
$0.5600 \pm .11$ $0.5592 \pm .11$
$0.5136 \pm .13$
$0.5701 \pm .36$
$0.5688 \pm .10$

0.97

0.96

0.81

0.84

0.94

$0.05606 \pm .03$ $0.05605 \pm .03$ $0.05536 \pm .08$ $0.05627 \pm .19$ $0.05621 \pm .04$

4. Peter Strides migmatite (NF-9)
a, $+105 \mathrm{M} 2$
0.131232
b, $+74 \mathrm{~N} 2$

0.067263
0.041244

$\begin{array}{lll}2518 & 51 & 18.2 \\ 4451 & 17 & 14.8 \\ 3384 & 12 & 17.5\end{array}$
3384
$\mathrm{Pb}=$ radiogenic; $\mathrm{Pb}_{\mathrm{c}}=$ common $\mathrm{Pb} ; \mathrm{R}=$ correlation of errors in isotope ratios. and $\mathrm{N}$ refer to magnetic and non-magnetic at side slope indicated in degrees.
2 measured ratio, corrected for spike and fractionation.
$3_{\text {total }}$ common $\mathrm{Pb}$ in analysis corrected for fractionation.
${ }^{4}$ radiogenic ${ }^{208} \mathrm{~Pb}$, expressed as \% of total radiogenic $\mathrm{Pb}$.

$0.06729 \pm .09$
$0.06718 \pm .09$
$0.06706 \pm .09$
$0.5129 \pm .12$

$0.5117 \pm .10$

$0.5100 \pm .11$

\subsection{8 \\ 0.94 \\ 0.91}

$0.05528 \pm .06$ $0.05524 \pm .04$ $0.05515 \pm .04$
$454.9 \pm 1.3$ $454.5 \pm 1.5$ $426.8 \pm 3.6$ $463.1 \pm 8.6$ $460.8 \pm 1.6$

$423.4 \pm 2.6$ $422.0 \pm 1.6$ $418.3 \pm 2.0$
Uncertainties are 1 standard error of mean in \% except ${ }^{207} \mathrm{~Pb} / 206 \mathrm{~Pb}$ age errors which are 2 standard errors in Ma.

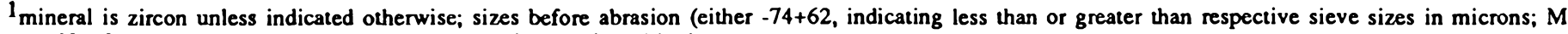




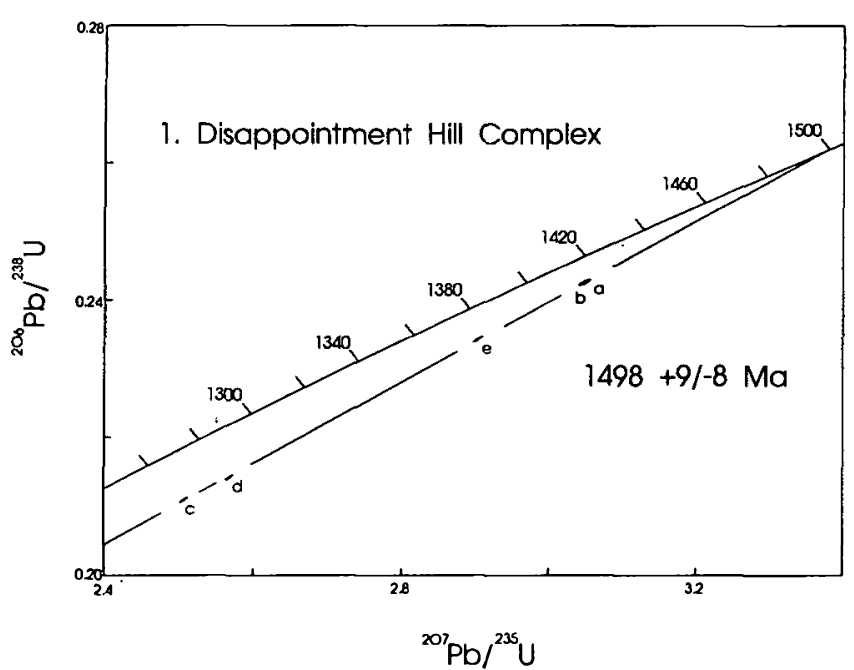

Fig. 3. Concordia plot showing zircon fractions for the Disappointment Hill complex.

evidence for a downward shift in the finest fraction. We interpret the upper intercept to be close to age of emplacement. The lower intercept age may represent a geological event (see below), but it may be composite effect of Grenville and later metamorphism, possibly including a minor component of zircon growth as well as $\mathrm{Pb}$ loss during Paleozoic metamorphic events.

\section{Hare Hill granite}

Data points for five fractions correspond to a linear array which lies close, and almost parallel, to concordia and spans about $10 \mathrm{Ma}$ (Fig. 4). Fractions $\mathrm{f}$ and $\mathrm{g}$ represent strongly abraded zircon populations in which length dimensions have been reduced by $50 \%$. As corresponding data points are concordant, the remaining slightly discordant data points are interpreted in terms of slight recent $\mathrm{Pb}$ loss. The explanation for the linear array is not obvious from the zircons which have a euhedral morphology and do not have visible cores. Extensive memory is not expected in any case in alkaline granites as zircon is more soluble in magmas with high $(\mathrm{Na}+\mathrm{K}+2 \mathrm{Ca}) /$ (Al+Si) ratios (Watson and Harrison, 1983). The data array is, therefore, more likely to be the result of marginal crystal $\mathrm{Pb}$ loss effects which may have been aided by reactive fluids passing through this alkaline rock during later Palaeozoic events. Two fractions of sphene have yielded imprecise $\mathrm{U}-\mathrm{Pb}$ ages in the $500 \mathrm{Ma}$ to $440 \mathrm{Ma}$ range, suggestive of Paleozoic events.

Four out of the eight data points $(a, b, c, f){ }^{207} \mathrm{~Pb} / 206 \mathrm{~Pb}$ model ages cluster within analytical uncertainty at $608.2 \mathrm{Ma}$ (607.6-609.1 Ma). Given the lack of metamorphic overgrowth, the extremely strong abrasion of fraction $f$, and the large size of fraction a, the igneous age is assigned at $608 \pm 4$ Ma.

\section{Cormacks Lake complex}

The four zircon data points for this granulite-facies rock are concordant to slightly discordant with a range of ${ }^{200} \mathrm{~Pb} /$

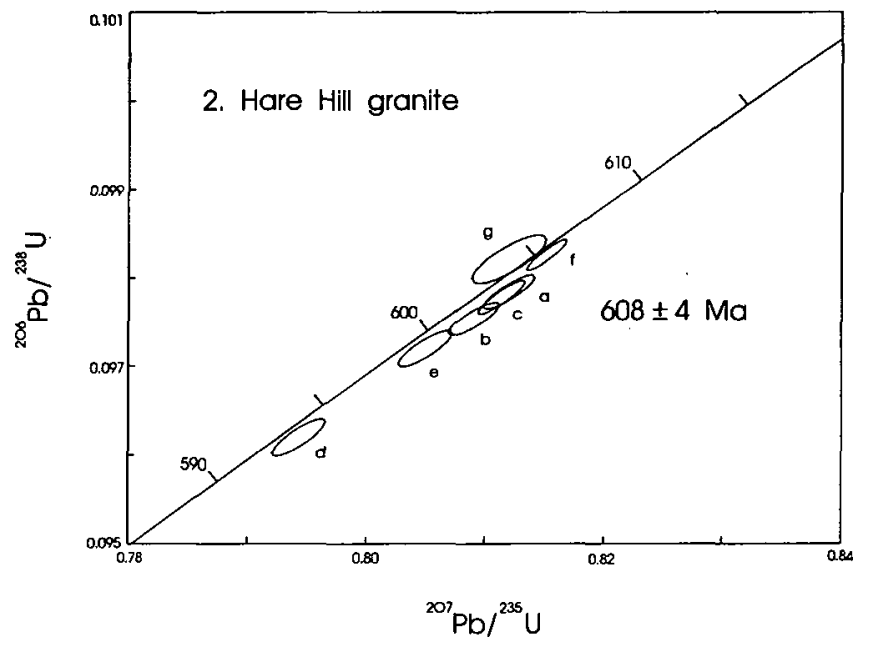

Fig. 4. Concordia plot showing zircon fractions for the Hare Hill granite.

${ }^{206} \mathrm{~Pb}$ model ages ranging from $463.1 \mathrm{Ma}$ to $426.8 \mathrm{Ma}$ (Fig. 5). The youngest model age for fraction $\mathrm{c}$ is surprising, as $\mathrm{K}-\mathrm{Ar}$ biotite ages of $447 \pm 8 \mathrm{Ma}$ and $449 \pm 8 \mathrm{Ma}$ and a K-Ar hornblende age of $455 \pm 14 \mathrm{Ma}$ have been reported from this area (Stevens et al., 1982). The low age for this slightly more magnetic and weakly abraded zircon fraction is interpreted in terms of radiogenic lead loss due to later, low-temperature tectonic events.

The two oldest fractions are in close agreement, yielding ${ }^{200} \mathrm{~Pb} /{ }^{208} \mathrm{~Pb}$ ages of $461 \mathrm{Ma}$ and $463 \mathrm{Ma}$ and ${ }^{206} \mathrm{~Pb} /{ }^{38} \mathrm{U}$ ages of $457 \mathrm{Ma}$. It is unlikely that these fractions represent mixtures of igneous and metamorphic zircon as etched sections of the zircons show that low U rims were very thin and were likely to have been removed by abrasion prior to analysis. Textures seen in thin section are consistent with slightly recrystallized primary igneous texture (Fig. 6). We therefore interpret this intrusion to have been emplaced at $460 \pm 10 \mathrm{Ma}$ under granulite-facies metamorphic conditions which were followed by rapid cooling.

\section{Peter Strides migmatite}

Data points corresponding to four zircon fractions for the oldest granitoid component of this migmatite give almost concordant results (Fig. 7). The finest fraction gave a concordant result of $418.3 \mathrm{Ma}$. The other three fractions plot slightly below concordia indicating the presence of a small amount of significantly older inheritance. The age for igneous crystallization of this unit is placed at $418 \pm 4 \mathrm{Ma}$.

\section{Discussion}

Our results demonstrate a complex Precambrian history west of the Long Range Fault. The oldest rocks, the Disappointment Hill complex, appear essentially identical in age and petrography with granulite-facies gneisses of the northern Long Range (Baadsgaard $e t$ al., in press), and similar lithologies have been reported from the Indian Head Range (Colman-Sadd, 1969). Basement of this character may be 


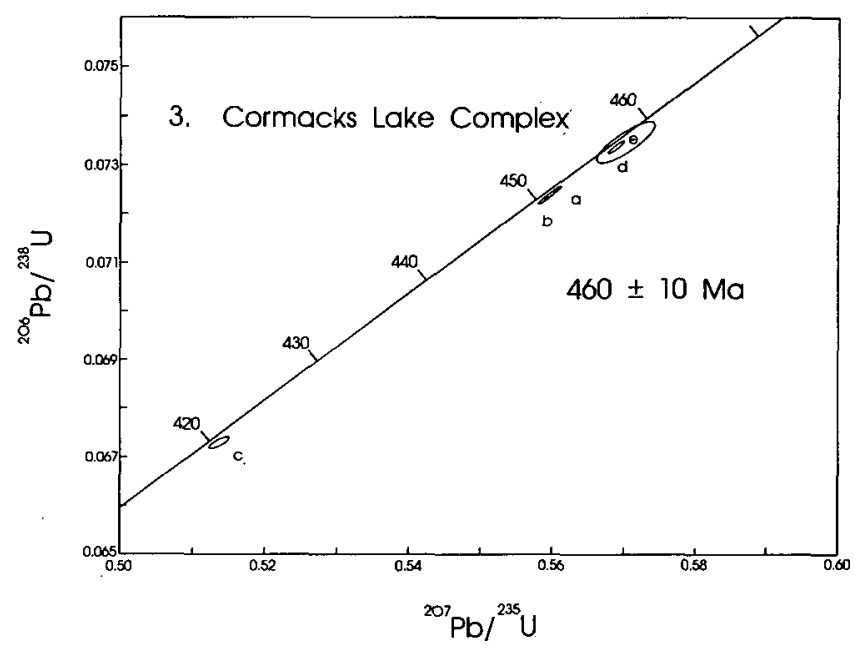

Fig. 5. Concordia plot showing zircon fractions for the Cormacks Lake complex.

present throughout western Newfoundland. The $840 \mathrm{Ma}$ lower intercept age resembles Ar-Ar ages obtained by Dallmeyer (1978) from rocks of the Indian Head Range. Such ages are distinctly younger than known Grenville events. Similar ages from Virginia have been interpreted by Rankin (1975) as dating rifting of Grenvillian basement prior to opening of the Iapetus Ocean.

Metasedimentary rocks of the Fleur de Lys Supergroup and latest Precambrian granitoid plutons like Hare Hill (see also Williams et al., 1985) complete a complex continental margin sequence. Williams et al. (1985) interpreted these latest Precambrian leucogranites in terms of a passive margin rifted in late Precambrian time. Similar ages for peralkaline leucogranites have been reported from the western Avalon Zone of Newfoundland (O'Brien et al., 1988), suggesting that the latest Precambrian rifting event split apart these regions (Williams et al., 1989).

The geometry of the thrust duplexes south of Grand Lake demonstrates that the metasedimentary rocks and their underlying gneissic basement originated east of the Long Range Fault which now truncates the duplexes. Therefore Precambrian rocks once occurred east of the Long Range Fault. No such rocks have been recognized in a form appropriate for sampling for geochronology. Large scale movements on the Long Range Fault must have removed the missing portions of thrust duplexes. We do not know the depositional ages of metasedimentary rocks in the Central Gneiss Subzone, but our results on the Cormacks Lake charnockite combined with earlier work on the tonalitic suite (Dunning, 1987; Stevens et al., 1982) clearly establish a mid-Ordovician age for plutonism and metamorphism and suggest rapid uplift so that $\mathrm{K}-\mathrm{Ar}$ and $\mathrm{U}-\mathrm{Pb}$ methods give similar results. These observations suggest that very high-grade metamorphic rocks southeast of the Long Range Fault cannot be directly correlated to those of the Steel Mountain Subzone, as argued by van Berkel and Currie (1988). The protolith of the metamorphic rocks of the Central Gneiss Subzone could be lower Ordovician or older in age. The occurrence of quartzite and carbonate, the paucity

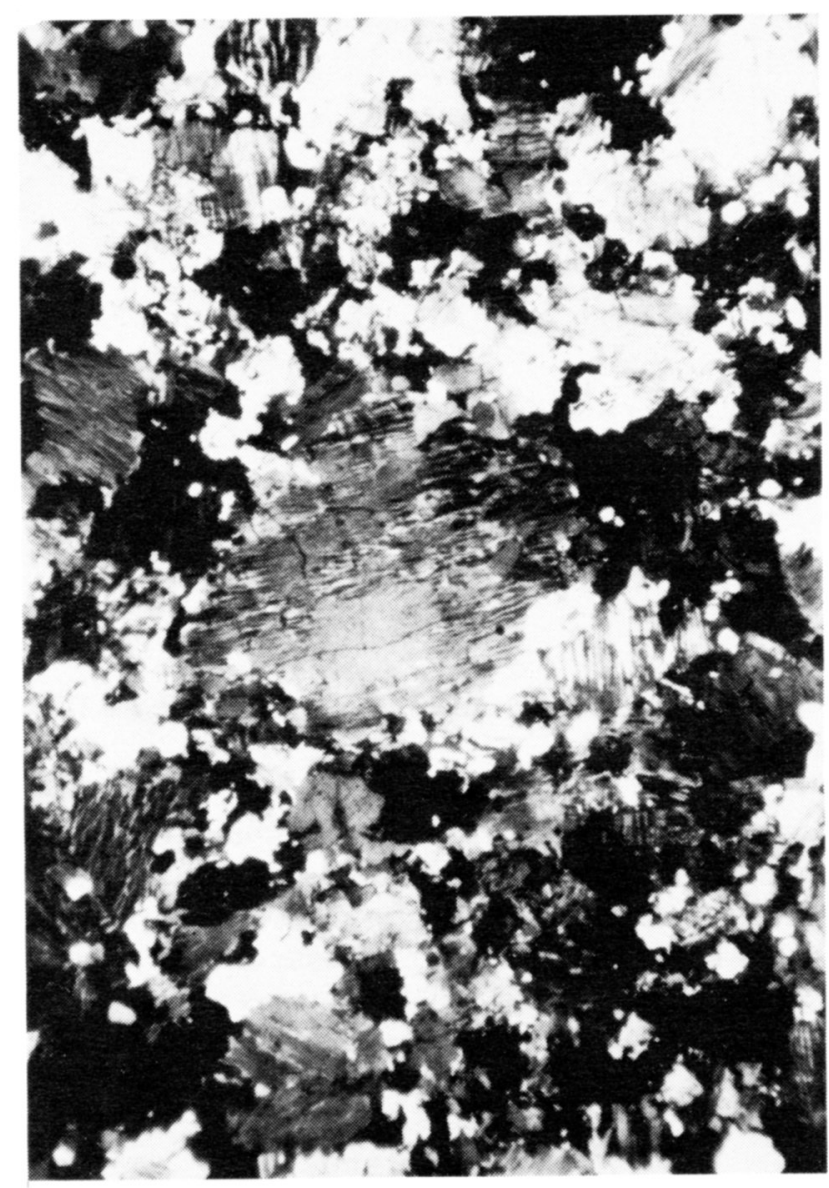

Fig. 6. Photomicrograph of charnockitic syenite from the Cormacks Lake complex. Note the large string mesoperthite grains, interpreted as original igneous grains, surrounded by finer-grained mosaic feldspar and quartz. Minor ortho-pyroxene, augite and hornblende also occur in the slide. Size of field $3.1 \times 4.5 \mathrm{~mm}$.

of mafic metavolcanic rocks, and the K-rich character of parts of the plutonic suite suggest they cannot be correlated to contemporary low-grade, mafic volcanic and ophiolitedominated rocks of the Dunnage Zone, as suggested by Dunning and Chorlton (1985). According to seismic evidence, the Central Gneiss Subzone may rest on Grenvillian basement (Kean et al., 1986; Marillier et al., 1988). The Notre Dame Subzone clearly overlies the Central Gneiss Subzone along its northern margin (van Berkel and Currie, 1988). The Central Gneiss Subzone could have formed lower continental slope deposits facies equivalent to the Fleur de Lys Supergroup west of the Long Range Fault. On this model, Ordovician metamorphism and plutonism accompanied thickening of the crust by collapse and imbrication to the west of a continental rise prism during eastward subduction.

Migmatites at Peter Strides Pond (418 $\pm 4 \mathrm{Ma})$ are younger than the contiguous, essentially unmetamorphosed ophiolitic Annieopsquotch complex (485 Ma, Dunning, 1987) and related slivers of Silurian rocks (429 Ma, Chandler and Dunning, 1983), which form the southern tip of Dunnage Zone rocks, and are also younger than both plutonism-metamorphism ( $\sim 65 \mathrm{Ma})$ and younger mafic plutons $(\sim 430 \mathrm{Ma})$ 


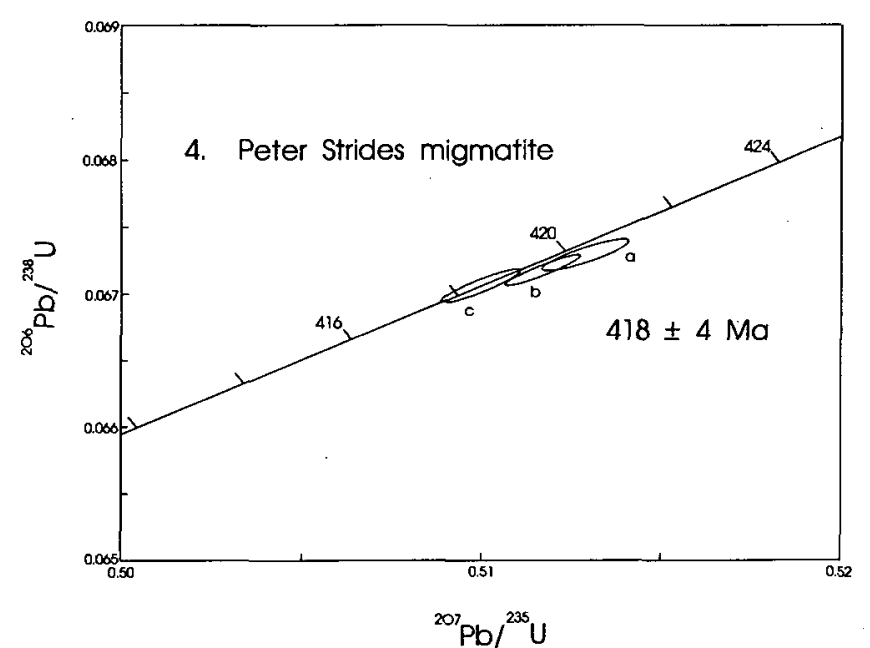

Fig. 7. Concordia plot showing zircon fractions for the Peter Strides migmatite.

in the Central Gneiss Subzone. Therefore the Victoria River Fault must exhibit large-scale motion younger than $418 \mathrm{Ma}$. We draw attention to the Long Range and Victoria River faults as major separators of radiometric ages. In the Steel Mountain Subzone and Central Gneiss Subzone, Precambrian ages occur only northwest of the Long Range Fault, and Ordovician ages occur only between the Long Range and Victoria River faults.

\section{Conclusions}

Crystalline rocks between the Grand Lake and southern Long Range faults appear to be entirely of Precambrian age. Felsic granulite-facies gneisses have ages of $1.5 \mathrm{Ga}$, like the northern Long Range, and massif anorthosites were emplaced in the 1.5 to $0.6 \mathrm{Ga}$ interval, like the Indian Head Range and northwestern Cape Breton Island. No plutons of ca. $1 \mathrm{Ga}$ age have been recognized, but metamorphism of this age may be significant. Late Precambrian plutons (610-600 Ma) occur only in transported slices originating east of the Long Range Fault. They are hosted by metasedimentary rocks thought to have formed part of the passive continental margin of North America. In the Central Gneiss Subzone, Precambrian plutons are absent or unrecognizable. The oldest recognizable plutons were emplaced under granulitefacies metamorphic conditions at $\sim 465 \mathrm{Ma}$ into a high-grade metamorphic host derived from mainly clastic sedimentary rocks. The depositional age and provenance of this host remain doubtful, but it was not derived from oceanic material of the Dunnage Zone. It could have been derived from continental slope deposits facies-equivalent to those in the Steel Mountain Subzone. Southeast of the Victoria River Fault, the oldest igneous ages are ca. $420 \mathrm{Ma}$, developed during pervasive migmatisation of psammitic metasedimentary rocks of uncertain, but probably Paleozoic age. These rocks are separated from the Central Gneiss Subzone and Exploits Subzone of the Dunnage Zone by the Victoria River Fault which appears to be the most profound lithological separator in southwestern Newfoundland. The age distribution and structure of the Steel Mountain Subzone, Central Gneiss Subzone and Meelpaeg Subzone are compatible with westward thrusting of subzones in post-early Silurian time.

\section{ACKNOWLEDgements}

This research was supported by the Canada-Newfoundland Mineral Development Agreement, 1984-1989.

BAadsgaArd, H., ERdmer, P., and OWen, J.V. In press. U-Pb and $\mathrm{Pb}-\mathrm{Pb}$ geochronology of the Long Range Inlier, Newfoundland. Canadian Journal of Earth Sciences.

BARR, S.M., RAESIDE, R.P., and VAN BreEmen, O. 1987. Grenvillian basement in the northern Cape Breton Highlands, Nova Scotia. Canadian Journal of Earth Sciences, 24, pp. 992-997.

BIRD, J.M. and DEWEY, J.F. 1971. Lithosphere plate-continental margin tectonics and the evolution of the Appalachian orogen. Geological Society of America Bulletin, 81, pp. 10311060.

Brown, P.A. 1977. Geology of the Port aux Basques area (110/ 11), Newfoundland. Newfoundland Department of Mines and Energy, Report 77-2, 11 p.

Chandler, F.W. and Dunning, G.R. 1983. Fourfold significance of an early Silurian $\mathrm{U}-\mathrm{Pb}$ zircon age from rhyolite in redbeds, southwest New foundland. Geological Survey of Canada, Paper 831B, pp. 419-421.

Colman-SADD, S.P. 1969. Geology of the iron deposits near Stephenville, Newfoundland. M.Sc. thesis, Memorial University of Newfoundland, Saint John's, Newfoundland, 97 p.

Colman-Sadd, S.P. and Swinden, H.S. 1984. A tectonic window in central Newfoundland?; geological evidence that the Appalachian Dunnage zone may be allochthonous. Canadian Journal of Earth Sciences, 21, pp. 1349-1367.

CURrie, K.L. 1987. A preliminary account of the geology of the Harry's River map-area, southern Long Range of Newfoundland. Geological Survey of Canada, Paper 87-1A, pp. 653662.

Currie, K.L. and van Berkel, J.T. 1989. Tectonic significance of mafic intrusions in the Central Gneiss terrane of southwestern Newfoundland. Atlantic Geology, 25, pp. 181-189.

Currie, K.L., Pajari, G.E., and Pickerill, R.K. 1979. Tectonostratigraphic problems in the Carmanville area, northeastern Newfoundland. Geological Survey of Canada, Paper 79-1A. pp. 71-76.

DAllmeyer, R.D. 1978. ${ }^{40} \mathrm{Ar} /{ }^{39} \mathrm{Ar}$ incremental release ages of hornblende and biotite from Grenville basement rocks within the Indian Head Range complex, southwest Newfoundland; their bearing on late Proterozoic-early Paleozoic history. Canadian Journal of Earth Sciences, 15, pp. 1374-1379.

DunNing, G.R. 1987. Geology of the Annieopsquotch ophiolite complex, southwest Newfoundland. Canadian Joumal of Earth Sciences, 24, pp. 1162-1174.

Dunning, G.R. and Chorlton, L.B. 1985. The Annieopsquotch ophiolite belt of southwest Newfoundland: geology and tectonic significance. Geological Society of America Bulletin, 96. pp. 1466-1476.

Dunning, G.R., Krogh, T.E., O'Brien, S.J., Colman-Sadd, S.P., and O'NeILL, P. 1988. Geochronologic framework of the central mobile belt in southern Newfoundland and the importance of Silurian orogeny. Geological Association of 
Canada, Program with Abstracts, 13, p. A34.

Fox, D. and VAN BERKEL, J.T. 1988. Mafic-ultramafic occurrences in metasedimentary rocks of southwestern Newfoundland. Geological Survey of Canada, Paper 88-1B, pp. 41-49.

Herd, R.K. and Dunning, G.R. 1979. Geology of Puddle Pond map-area, southwestern Newfoundland. Geological Survey of Canada, Paper 79-1 A, pp. 305-310.

HeYl, A.V. and Ronan, J.J. 1954. The iron deposits of Indian Head area. Geological Survey of Canada Bulletin, 27, pp. 4262.

Hibbard, J. 1983. Notes on the metamorphic rocks in the Corner Brook area (12A/13) and regional correlation of the Fleur de Lys belt, western Newfoundland. Newfoundland Department of Mines and Energy, Mineral Development Division, Report 83-1, pp. 41-50.

Kean, C.E., Kean, M.J., Nichols, B., Reid, I., Stockmal, G.S., Colman-Sadd, S.P., O'Brien, S.J., Miller, H., Quinlan, G., Williams, H., and Wright, W.J. 1986. Deep seismic reflection profile across the northern Appalachians. Geology, 14, pp. 141-145.

KnapP, D.A., Kennedy, D.P., and Martineau, Y. 1979. Stratigraphy, structure and regional correlation of rocks at Grand Lake, western Newfoundland. Geological Survey of Canada, Paper 79-1A, pp. 317-325.

KROGH, T.E. 1982. Improved accuracy of U-Pb ages by the creation of more concordant systems using an air abrasion technique. Geochimica et Cosmochimica Acta, 46, pp. 637. 649.

Leech, G.B., Lowdon, J.A., Stockwell, C.H., and Wanless, R.K. 1963. Age determinations and geological studies. Geological Survey of Canada, Paper 61-17, 140 p.

Lowdon, J.A., Stockwell, C.H., Tipper, H.W., and Wanless, R.K. 1963. Age determinations and geological studies. Geological Survey of Canada, Paper 62-17, 140 p.

Marillier, F., Keen, C.E., Stockmal, G.S., Quinlan, G., Williams, H., Colman-Sadd, S.P., and O'Brien, S.J. 1989. Deep structure and surface zonation of the Canadian Appalachians. Canadian Journal of Earth Sciences, 26, pp. 305-321.

Murthy, G.S. and RAO, V.K. 1976. Paleomagnetism of the Steel Mountain and Indian Head anorthosites from western Newfoundland. Canadian Journal of Earth Sciences, 13, pp. 7583.

Nowlan, G.S. and Thurlow, J.G. 1987. Middle ordovician conodonts from the Buchans Group. Geological Survey of Canada, Paper 86-24, pp. 59-62.

O'Brien, S.J., O'Neill, P.P., King, A.F., and Black wood, R.F. 1988. Eastern margin of the Newfoundland Appalachians - a cross-section of the Avalon and Gander zones. Geological Association of Canada/Mineralogical Association of Canada Field Trip Guidebook, Trip B4, 126 p.

Parrish, R.R., Roddick, J.C., Loveridge, W.D., and Sullivan, R.W. 1987. Uranium-lead analytical techniques at the geochronology laboratory, Geological Survey of Canada. Geological Survey of Canada, Paper 87-2, pp. 3-9.

Rankin, D.W. 1975. The continental margin of eastern North America in the southern Appalachians: the opening and closing of the Proto-Atlantic Ocean. American Journal of Science, 275-A, pp. 298-336.

RiLeY, G.C. 1962. Stephenville map-area, Newfoundland. Geological Survey of Canada, Memoir 323, 72 p.

Stevens, R.D., Delabio, R.N., and Lachance, G.R. 1982. Age determinations and geologic studies: $\mathrm{K}$-Ar isotopic ages,
Report 16. Geological Survey of Canada, Paper 82-2, 48 p. van Berkel, J.T. 1987. Geology of the Dashwoods Pond, St. Fintan's and Main Gut map areas, southwest Newfoundland. Geological Survey of Canada, Paper 87-1, pp. 399-408.

van Berkel, J.T. and Currie, K.L. 1988. Geology of the Puddle Pond (12A/5) and Little Grand Lake (12A/12) map areas, southwestern Newfoundland. Newfoundland Department of Mines, Mineral Development Division, Report 88-1, pp. 99107.

WATSON, E.B. and HARRISON, T.M. 1983. Zircon saturation revisited: temperature and composition effects in a variety of crustal magma types. Earth and Panetary Science Letters, 64, pp. 295-304.

Whalen, J.B. and Currie, K.L. 1990. The Topsails suite, western Newfoundland: fractionation and magma-mixing in an "orogenic" A-type suite. In Ore-bearing Granite Systems; Petrogenesis and Mineralizing Processes. Edited by H.J. Stein and J.L. Hannah. Geological Society of America, Special Paper 246, pp. 287-300.

Whalen, J.B., Currie, K.L., and van Breemen, O. 1987. Episodic Ordovician-Silurian magmatism in the Topsails Igneous terrane, western Newfoundland. Transactions of the Royal Society of Edinburgh, 78, pp. 17-28.

Williams, H. 1978. Tectonic-lithofacies map of the Appalachian orogen. Memorial University of Newfoundland Map 1, Saint John's.

1979. Appalachian Orogen in Canada. Canadian Journal of Earth Sciences, 16, pp. 792-807.

Williams, H. and Cawood, P.A. 1986. Relationships along the eastern margin of the Humber Arm allochthon between Georges Lake and Corner Brook, western Newfoundland. Geological Survey of Canada, Paper 86-1 A, pp. 759-765.

Williams, H. and Stevens, R.K. 1974. The ancient continental margin of eastern North America. In The geology of continental margins. Edited by C.A. Burk and C.L. Drake. Springer-Verlag, New York, pp. 781-796.

Williams, H., Gillespie, R.T., and van Breemen, O. 1985. A late Precambrian rift-related igneous suite in western Newfoundland. Canadian Journal of Earth Sciences, 22, pp. 1727. 1735.

Williams, H., Colman-Sadd, S.P., and Swinden, H.S. 1988. Tectonic-stratigraphic subdivisions of central Newfoundland. Geological Survey of Canada, Paper 88-1A, pp. 91-98.

Williams, H., Dickson, W.L., Currie, K.L., Hayes, J.P., and TUACH, J. 1989. Preliminary report on a classification of Newfoundland granitic rocks and their relations to tectonostratigraphic zones and lower crustal blocks. Geological Survey of Canada, Paper 89-1B, pp. 47-54.

York, D. 1969. Least squares fitting of a straight line with correlated errors. Earth and Planetrary Science Letters, 5, pp. 320-324.

\section{APPENDIX 1: Description of zircon samples}

\section{(1) Disappointment Hill complex (NF-7)}

The zircon concentrate was abundant but mostly less than 100 microns in size. The crystals formed doubly terminated euhedral prisms with length to breadth ratios about 3:1, and no evidence of cores or overgrowths. Etching with HF did not reveal zoning, but the $U$ content of the zircons is so 
low $(150 \mathrm{ppm})$ that little differential etching could be expected. The zircons are of igneous morphology, and metamorphic zircon growth seems likely to be negligible or minor.

(2) Hare Hill granite (86-Z1)

This specimen yielded an abundant crop of large zircons ( $>150$ microns) consisting of stubby, doubly terminated prisms with length to breadth ratios of $2: 3$. About $5 \%$ of zircons exhibit geniculate or penetrative twinning. Most have ruststained surfaces, but they exhibit no evident cores or metamorphic overgrowths, even after etching with HF, and appear entirely of igneous derivation. Sphene in this rock forms euhedral colourless grains similar in size to zircon and locally associated with it.

(3) Cormacks Lake complex (NF-2)

The zircon crop from this homogeneous leucocratic charnockite was abundant, including crystals up to $1 \mathrm{~mm}$ long. Large crystals approach 1:1 length to breadth ratios, while smaller crystals are more prismatic, up to 4:1. All form doubly terminated euhedral prisms without visible cores or overgrowths. However, etching with HF showed that the zircons contain euhedral, somewhat patchy, U-rich cores and very thin U-poor rims which do not truncate or cross-cut the cores. The zircon appears to be entirely of igneous origin. The zircon concentrate from this locality contained a significant amount of molybdenite.

\section{(4) Peter Strides Pond migmatite (NF-9)}

Granitoid lenticles from the migmatite yielded a moderately abundant crop of small zircons ( $<100$ microns) consisting of doubly terminated prisms with length to breadth ratios of 3:1 to $4: 1$. They exhibit no evident cores or metamorphic overgrowths, even after etching with HF. 